\title{
KORELASI PANJANG TUNGKAI, POWER OTOT TUNGKAI DAN KECEPATAN LARI DENGAN HASIL LOMPAT JAUH
}

\section{CORRELATION OF LENGTH OF THE LENGTH, MUSCLE POWER AND RUNNING SPEED WITH THE RESULT}

\author{
${ }^{1}$ Arief Ibnu Haryanto, ${ }^{2}$ Nurhayati Liputo, ${ }^{3}$ Iwan Fataha \\ ${ }^{1,3}$ Program Studi Ilmu Keolahragaan, Fakultas Keguruan dan Ilmu Pendidikan \\ Universitas Muhammadiyah Gorontalo \\ ${ }^{2}$ Program Studi Pendidikan Kepelatihan Olahraga, Fakultas Olahraga dan Kesehatan \\ Universitas Negeri Gorontalo \\ E-mail: ariefibnu67@gmail.com
}

\begin{abstract}
ABSTRAK
Tujuan penelitian ini untuk mengetahui korelasi panjang tungkai, power otot tungkai dan kecepatan lari dengan hasil lompat jauh gaya menggantung. Penelitian ini merupakan penelitian korelasional. Populasi penelitian ini yaitu mahasiswa Ilmu Keolahragaan, Fakultas Keguruan dan Ilmu Pendidikan, Universitas Muhammadiyah Gorontalo yang mempunyai populasi 16 mahasiswa aktif. Sampel penelitian ini merupakan seluruh populasi (total sampling). Intrumen dalam penelitian ini menggunakan dari telapak kaki secara vertikal sampai dengan titik trochanter mayor untuk panjang tungkai, Standing Board (Long Jump) Test untuk power otot tungkai, tes kecepatan lari menggunakan kecepatan lari 100 meter. Hasil dari penelitian ini mengemukakan bahwa hasil lompat jauh mempunyai korelasi korelasi yang tinggi atau kuat terhadap panjang tungkai, power otot tungkai, dan kecepatan lari. Adapun koefisien korelasi bersama terhadap hasil lompat jauh adalah sangat tinggi.
\end{abstract}

Kata Kunci: panjang tungkai; power otot tungkai; lompat jauh

\section{ABSTRACT}

The purpose of this study was to determine the correlation between leg length, leg muscle power and running speed with the hanging style long jump results. This research is a correlational research. The population of this study were students of Sport Science, Faculty of Teacher Training and Education, University of Muhammadiyah Gorontalo which had a population of 16 active students. The research sample is the entire population (total sampling). The instrument in this study used the vertical foot of the foot to the major trochanter point for the leg length, the Standing Board (Long Jump) Test for leg muscle power, the running speed test using a running speed of 100 meters. The results of this study suggest that the long jump results have a high or strong correlation with leg length, leg muscle power, and running speed. The co-correlation coefficient on the long jump result is very high.

Keywords: leg length; leg muscle power; long jump 


\section{Pendahuluan}

Berbicara tentang olahraga, tentu masyarakat awam sudah tidak asing lagi dengan olahraga atletik. Atletik sendiri dapat dikatakan sebagai ibu dari seluruh cabang olahraga yang ada, karena dalam atletik menggunakan keterampilan dasar dalam bergerak (Liputo \& Biki, 2019). Nomor atletik yang sering diperlombakan yaitu nomor jalan, lari, lempar dan lompat (Jarver, 2014).

Nomor lompat sendiri terdiri dari beberapa kategori, yaitu lompat tinggi, lompat jangkit, lompat galah, dan lompat jauh (Hastuti, 2009). Lompat jauh merupakan salah satu dari nomor atletik yang bertujuan untuk dapat melompat di satu titik ke titik yang lain sejauh-jauhnya tanpa melanggar aturan.

Konsep fase-fase dalam lompat jauh terdiri atas awalan, tolakan, melayang dan mendarat (Sidik, 2014). Tentu pada konsep fase-fase tersebut fase awalan akan melibatkan panjang tungkai, dan juga kecepatan lari. Fase tolakan akan melibatkan panjang tungkai dan power otot tungkai. Kemudian fase melayang akan melibatkan lentingan punggung dan kecepatan dalam fase awalan untu menambah dorongan ke depan. Fase mendarat dan yang paling akhir banyak melibatkan keseimbangan dan panjang tungkai. Sedangkan komponen biomotorik yang dominan dalam lompat jauh yaitu komponen biomotorik yang dapat diperhatikan, diantaranya kordinasi, kelentukan, power atau daya ledak, kekuatan, kelincahan, dan salah satu faktor yang juga mempengaruhi yaitu bentuk telapak kaki (Hermawan \& Tarsono, 2017).

Panjang tungkai yaitu jarak vertikal telapak kaki sampai dengan pangkal paha yang diukur dengan cara berdiri tegak (Kuswahyudi \& Nurdin, 2017). Seseorang yang mempunyai tungkai yang panjang, secara logis akan mempunyai keuntungan dalam berlari dan juga melompat. Karena dalam berlari akan memiliki jangkauan yang lebih luas dan juga dalam lompatan akan memiliki jangkauan yang luas pula.

Power otot tungkai merupakan hasil kali antara kekuatan dan kecepatan pada otot tungkai (Ismadraga \& Lumintuarso, 2015). Sehingga dalam fase bertolak, seseorang yang memiliki power otot tungkai yang baik akan memperoleh keunggulan dalam melompat dari satu titik ke titik yang lainnya (bak lompatan) yang akan memperoleh jangkauan yang lebih jauh.

Kecepatan merupakan waktu yang dibutuhkan untuk perpindahan dibagi dengan jarak yang ditempuh (Henjilito, 2017). Sedangkan kecepatan lari merupakan perpindahan dibagi dengan jarak yang ditempuh saat berlari (Sari, 2015). Kecepatan yang seperti ini merupakan hal 
yang penting dalam fase awalan pada saat berlari ancang-ancang.

Peneliti menyadari bahwa beberapa hal tersebut semisal panjang tungkai, power otot tungkai, dan juga kecepatan berlari berhubungan erat dengan hasil lompat jauh. Namun peneliti belumlah menemukan penelitian yang mengemukakan seberapa eratkah hubungan panjang tungkai, power otot tungkai, dan juga kecepatan berlari terhadap lompat jauh secara spesifik terutama untuk gaya menggantung.

Penelitian yang sejenis dengan penelitian ini yang berjudul hubungan antara kecepatan lari, power tungkai dan panjang tungkai dengan kemampuan lompat jauh gaya jongkok siswa putra Kelas X SMA N 1 Karanganyar Kabupaten Kebumen (Humami, 2012). Memiliki beberapa perbedaan dengan penelitian ini, yaitu perbedaan dalam tujuan penelitian yang dalam penelitian ini memaparkan berapa keeratan dari panjang tungkai, power otot tungkai, dan juga kecepatan berlari terhadap lompat jauh. Kemudian dari segi sampel yang pada penelitian ini menggunakan mahasiswa Ilmu Keolahragaan, Fakultas Keguruan dan Ilmu Pendidikan, Universitas Muhammadiyah Gorontalo yang notabene memiliki kecerdasan kinestetik yang lebih unggul daripada siswa SMA yang kurang terlatih dalam fisiknya. Kemudian dari segi jenis lompatan yang menggunakan gaya menggantung.

Melalui pemaparan tersebut, peneliti merasa penting untuk melakukan sebuah penelitian yang menitikberatkan variabel panjang tungkai, power otot tungkai, dan juga kecepatan berlari terhadap lompat jauh secara spesifik terutama untuk gaya menggantung kepada mahasiswa Ilmu Keolahragaan, Fakultas Keguruan dan Ilmu Pendidikan, Universitas Muhammadiyah Gorontalo.

\section{Metode Penelitian}

Penelitian ini merupakan penelitian korelasional yang diperuntukkan untuk mengetahui ada atau tidaknya hubungan antara kedua atau beberapa variabel (Arikunto, 2010). Subjek dalam penelitian ini yaitu mahasiswa Ilmu Keolahragaan, Fakultas Keguruan dan Ilmu Pendidikan, Universitas Muhammadiyah Gorontalo yang mempunyai populasi 16 mahasiswa aktif. Sampel penelitian ini diambil dari seluruh populasi mahasiswa Ilmu Keolahragaan, Fakultas Keguruan dan Ilmu Pendidikan, Universitas Muhammadiyah Gorontalo (total sampling) dengan menerapkan protokol kesehatan secara ketat.

Instrumen dalam penelitian ini untuk panjang tungkai menggunakan meteran jahit yang diukur dari telapak kaki secara vertikal sampai dengan titik trochanter mayor, instrumen power 
otot tungkai diukur menggunakan Standing Board (Long Jump) Test, tes kecepatan lari menggunakan kecepatan lari 100 meter.

Teknik analisis data dalam penelitian ini diperoleh dari penelitian ini dilanjutkan dengan menganalisis data kemudian ditarik kesimpulan dengan menggunakan statistik parametrik yang meliputi uji prasyarat (uji normalitas, uji linieritas), dan uji hipotesis menggunakan SPSS 22.

Adapun pengujian hipotesis yang akan digunakan dalam penelitian ini yaitu:

1. Ada hubungan panjang tungkai terhadap hasil lompat jauh.

2. Ada hubungan power otot tungkai terhadap hasil lompat jauh.

3. Ada hubungan kecepatan lari terhadap hasil lompat jauh

4. Ada hubungan panjang tungkai, power otot tungkai dan kecepatan lari terhadap hasil lompat jauh

Sedangkan pedoman untuk menentukan keeratan hubungan yaitu:

$\mathrm{KK}=0$, tidak ada korelasi

$0<\mathrm{KK} \leq 0,20$, korelasi sangat terendah atau lemah sekali.

$0,20<\mathrm{KK} \leq 0,40$, korelasi rendah atau lemah tapi pasti.

$0,40<\mathrm{KK} \leq 0,70$, korelasi yang cukup berarti.

$0,70<\mathrm{KK} \leq 0,90$, korelasi yang tinggi atau kuat.

$0,90<\mathrm{KK}<1,00$, korelasi sangat tinggi.

$\mathrm{KK}=1$, korelasi sempurna.

\section{Hasil Penelitian}

Secara ringkas, deskripsi penelitian ini adalah sebagai berikut:

Tabel 1. Deskripsi Statistik

\begin{tabular}{lcccc}
\hline \multicolumn{1}{c}{ Statistik } & Panjang Tungkai & Power Otot Tungkai & Kecepatan Lari & Lompat Jauh \\
\hline $\mathrm{N}$ & 16 & 16 & 16 & 16 \\
\hline Mean & 96 & 2.1219 & 10.1875 & 3.85 \\
\hline Median & 96 & 2.1250 & 10.2 & 3.825 \\
\hline Std. Dev & 1.12546 & .06575 & .06952 & .10646 \\
\hline Minimum & 94 & 2 & 10.05 & 3.65 \\
\hline Maximum & 98.50 & 2.25 & 10.35 & 4.10 \\
\hline
\end{tabular}

Analisis data untuk menguji hipotesis memerlukan beberapa uji persyaratan yang harus dipenuhi agar hasilnya dapat dipertanggungjawabkan. Berikut ini merupakan uji normalitas yang bertujuan untuk mengetahui apakah data dari tiap variabel berdistribusi normal atau tidak. Untuk 
mengetahui apakah sebaran berdistribusi normal yaitu apabila suatu sebaran adalah $\mathrm{p}>0.05$ sebaran dinyatakan normal, dan jika $\mathrm{p}<0.05$ sebaran dikatakan tidak normal. Rangkuman hasil uji normalitas adalah sebagai berikut:

Tabel 2. Rangkuman Uji Normalitas

\begin{tabular}{ccccc}
\hline Variabel & $p$ & Sig. & Keterangan \\
\hline Panjang Tungkai & 0.136 & & & Normal \\
\cline { 1 - 2 } \cline { 5 - 6 } Power Otot Tungkai & 0.200 & & & \\
\cline { 1 - 2 } \cline { 5 - 6 } Kecepatan Lari & 0.183 & & & Normal \\
\hline Lompat Jauh & 0.09 & & & Normal \\
\hline
\end{tabular}

Hasil dari uji normalitas mengemukakan bahwa nilai signifikansi ( $p$ ) adalah lebih besar dari 0.05 , jadi, data adalah berdistribusi normal.

Selanjutnya persyaratan kedua merupakan uji liniearitas yang bertujuan untuk mengetahui apakah hubungan variabel terikat dengan variabel bebas linier sebagai berikut:

Tabel 3. Rangkuman Uji Linieritas

\begin{tabular}{ccc}
\hline $\begin{array}{c}\text { Hubungan } \\
\text { Fungsional }\end{array}$ & Sig. & Keterangan \\
\hline $\mathrm{X}_{1} . \mathrm{Y}$ & 0.204 & Linier \\
\hline $\mathrm{X}_{2} \mathrm{Y}$ & 0.212 & Linier \\
\hline $\mathrm{X}_{3} . \mathrm{Y}$ & 0.107 & Linier \\
\hline
\end{tabular}

Hasil dari uji linieritas mengemukakan bahwa nilai Sig. lebih besar daripada 0,05. Maka dari uji linieritas $\mathrm{X}$ terhadap $\mathrm{Y}$ dinyatakan linier.

Setelah melakukan uji prasyarat analisis, maka yang terakhir merupakan uji hipotesis. Penelitian ini menggunakan uji hipotesis analisis korelasi pearson dengan SPSS 22. Hasilnya adalah sebagai berikut:

Tabel 4. Koefisien Korelasi antara $\mathrm{X}_{1}$ terhadap Y

\begin{tabular}{cc}
\hline Hubungan Antar Variabel & Keoefisien Korelasi \\
\hline $\mathrm{X}_{1} . \mathrm{Y}$ & 0.849 \\
\hline $\mathrm{X}_{2} \mathrm{Y}$ & 0.833 \\
\hline $\mathrm{X}_{3 . \mathrm{Y}}$ & -0.856 \\
\hline $\mathrm{X}_{1,2,3 . \mathrm{Y}}$ & 0.910 \\
\hline
\end{tabular}

\section{Pembahasan}

\section{Korelasi Panjang Tungkai dengan Hasil Lompat Jauh}

Berdasarkan hasil analisis data hasil penelitian dapat diketahui bahwa panjang tungkai 
mempunyai korelasi yang tinggi atau kuat sebesar 0.849 terhadap hasil lompat jauh mahasiswa Ilmu Keolahragaan, Fakultas Keguruan dan Ilmu Pendidikan, Universitas Muhammadiyah Gorontalo.

Pemaparan tersebut senada dengan penelitian yang mengemukakan bahwa ada hubungan yang signifikan antara panjang tungkai dengan kemampuan lompat jauh (Mardiana, 2017). Penelitian ini memberikan penguatan bahwa ada korelasi antara panjang tungkai dengan hasil lompat jauh.

Pelatih yang jeli dalam memanfaatkan hasil penelitian ini, akan segera melakukan pengukuran panjang tungkai atletnya dalam rangka mengoptimalkan hasil prestasi atletnya dan juga akan memberikan wawasan yang lebih dalam menyeleksi bibit atlet lompat jauh yang ada.

\section{Korelasi Power Otot Tungkai dengan Hasil Lompat Jauh}

Berdasarkan hasil analisis data hasil penelitian dapat diketahui bahwa power otot tungkai mempunyai korelasi yang tinggi atau kuat sebesar 0.833 terhadap hasil lompat jauh mahasiswa Ilmu Keolahragaan, Fakultas Keguruan dan Ilmu Pendidikan, Universitas Muhammadiyah Gorontalo.

Pemaparan tersebut senada dengan penelitian yang mengemukakan bahwa ada hubungan yang signifikan antara daya ledak dengan kemampuan lompat jauh (Hasbunallah, 2018). Penelitian ini memberikan penguatan bahwa ada korelasi antara power otot tungkai dengan hasil lompat jauh.

Pelatih yang jeli dalam memanfaatkan hasil penelitian ini, akan segera mengevaluasi program latihan dalam meningkatkan kondisi fisik power otot tungkai dari atletnya. Beberapa jenis variasi latihan yang telah terbukti meningkatkan power otot tungkai yang bisa diterapkan yaitu quarter squat jump, knee tuck jump (Nur \& Hidayah, 2017) Squat jump dengan metode interval pendek (Santosa, 2015) dan lain-lain dengan harapan untuk dapat meningkatkan power otot tungkai lompat jauh.

\section{Korelasi Kecepatan Lari dengan Hasil Lompat Jauh}

Berdasarkan hasil analisis data hasil penelitian dapat diketahui bahwa kecepatan lari mempunyai korelasi yang tinggi atau kuat sebesar -0.856 terhadap hasil lompat jauh mahasiswa Ilmu Keolahragaan, Fakultas Keguruan dan Ilmu Pendidikan, Universitas Muhammadiyah 
Gorontalo.

Pemamaparan tersebut mempunya koefisien korelasi negatif yang berarti semakin kecil atau semakin sedikit waktu tempuh maka akan semakin baik. Penelitian tersebut senada dengan penelitian yang mengemukakan bahwa kecepatan lari mempunyai korelasi terhadap hasil lompat jauh (Anwar et al., 2020). Beberapa jenis variasi latihan yang telah terbukti meningkatkan kecepatan lari (speed) yang bisa diterapkan yaitu cone drill (Diputra, 2015), double leg speed hop dan double leg box bound (Sartono, 2018) dan lain-lain dengan harapan untuk dapat meningkatkan kecepatan lari secara optimal dalam awalan lompat jauh.

\section{Korelasi Panjang Tungkai, Power Otot Tungkai dan Kecepatan Lari terhadap Hasil Lompat Jauh}

Berdasarkan hasil analisis data hasil penelitian dapat diketahui bahwa ada hubungan bersama antara panjang tungkai, power otot tungkai dan kecepatan lari terhadap hasil lompat jauh mahasiswa Ilmu Keolahragaan, Fakultas Keguruan dan Ilmu Pendidikan, Universitas Muhammadiyah Gorontalo.

Korelasi bersama antara panjang tungkai, power otot tungkai dan kecepatan lari terhadap hasil lompat jauh mempunyai keoefisien korelasi sangat tinggi yaitu 0.910. hal ini mestinya mendorong pelatih untuk lebih memaksimalkan proses pembibitan dengan mengedepankan panjang tungkai sebagai analisa awal dalam memilih atlet, kemudian melatih fisik power otot tungkai dan kecepatan lari secara progresif dalam mengoptimalkan prestasi.

\section{Kesimpulan}

Adapun penelitian ini memiliki beberapa kesimpulan yang diperoleh, diantaranya yaitu:

1. Panjang tungkai mempunyai korelasi yang tinggi atau kuat sebesar 0.849 terhadap hasil lompat jauh mahasiswa Ilmu Keolahragaan, Fakultas Keguruan dan Ilmu Pendidikan, Universitas Muhammadiyah Gorontalo.

2. Power otot tungkai mempunyai korelasi yang tinggi atau kuat sebesar 0.833 terhadap hasil lompat jauh mahasiswa Ilmu Keolahragaan, Fakultas Keguruan dan Ilmu Pendidikan, Universitas Muhammadiyah Gorontalo.

3. Kecepatan lari mempunyai korelasi yang tinggi atau kuat sebesar -0.856 terhadap hasil lompat jauh mahasiswa Ilmu Keolahragaan, Fakultas Keguruan dan Ilmu Pendidikan, 
Universitas Muhammadiyah Gorontalo.

4. Korelasi bersama antara panjang tungkai, power otot tungkai dan kecepatan lari terhadap hasil lompat jauh mempunyai keoefisien korelasi sangat tinggi yaitu 0.910 terhadap hasil lompat jauh mahasiswa Ilmu Keolahragaan, Fakultas Keguruan dan Ilmu Pendidikan, Universitas Muhammadiyah Gorontalo.

\section{Referensi}

Anwar, Y. S., Hardiansyah, S., \& Asnaldi, A. (2020). Kontribusi Kecepatan dan Daya Ledak terhadap Hasil Lompat Jauh pada Siswa SMP Negeri 2 Lengayang. Sport Science. https://doi.org/10.24036/jss.v20i1.35

Arikunto, S. (2010). Prosedur Penelitian Suatu Pendekatan Praktik. Rineka Cipta.

Diputra, R. (2015). Pengaruh Latihan Three Cone Drill, Four Cone Drill, Dan Five Cone Drill Terhadap Kelincahan (Agility) Dan Kecepatan (Speed). Jurnal SPORTIF: Jurnal Penelitian Pembelajaran. https://doi.org/10.29407/js_unpgri.v1i1.574

Hasbunallah, H. (2018). Hubungan Antara Panjang Tungkai Dan Daya Ledak Tungkai Dengan Kemampuan Lompat Jauh Siswa SMP Negeri 1 Balusu. SPORTIVE: Journal Of Physical Education, Sport and Recreation. https://doi.org/10.26858/sportive.v1i2.6391

Hastuti, P. (2009). Buku Panduan Cabang Olahraga Atletik Special Olympics. In Journal of Chemical Information and Modeling.

Henjilito, R. (2017). Pengaruh Daya Ledak Otot Tungkai, Kecepatan Reaksi dan Motivasi terhadap Kecepatan Lari Jarak Pendek 100 Meter pada Atlet PPLP Provinsi Riau. Journal Sport Area. https://doi.org/10.25299/sportarea.2017.vol2(1).595

Hermawan, I., \& Tarsono, T. (2017). Hubungan Bentuk Telapak Kaki, Panjang Tungkai Dengan Daya Ledak Otot Tungkai Terhadap Atlet Kids Athletics Putri 11-14 Tahun Rawamangun. Journal Physical Education, Health and Recreation. https://doi.org/10.24114/pjkr.v1i2.7564

Humami, A. (2012). Hubungan Antara Kecepatan Lari, Power Tungkai dan Panjang Tungkai dengan Kemampuan Lompat Jauh Gaya Jongkok Siswa Putra Kelas X SMA N 1 Karanganyar Kabupaten Kebumen. Prodi Pendidikan Jasmani Kesehatan Dan Rekreasi.

Ismadraga, A., \& Lumintuarso, R. (2015). Pengembangan Model Latihan Kribo Untuk Power Tungkai Atlet Lompat Jauh dan Sprinter SKO SMP. Jurnal Keolahragaan. https://doi.org/10.21831/jk.v3i1.4966

Jarver, J. (2014). Belajar dan Berlatih Atletik. Pionir Jaya.

Kuswahyudi, K., \& Nurdin, F. (2017). Hubungan Bentuk Telapak Kaki Panjang Tungkai dengan Daya Ledak Otot Tungkai terhadap Atlet Kids Athletics Putri 11-14 Tahun. SEGAR. https://doi.org/10.21009/segar.0502.05

Liputo, N., \& Biki, R. (2019). Running Sport Program 50 Meters Number Of Long Jump. Jambura Journal of Sports Coaching. https://doi.org/10.37311/jjsc.v1i1.2010

Mardiana. (2017). JIKAP PGSD : Jurnal Ilmiah Ilmu Kependidikan Analisis Daya Ledak Tungkai , Kecepatan Lari Dan Panjang Tungkai Terhadap JIKAP PGSD: Jurnal Ilmiah Ilmu Kependidikan. Ilmu Kependidikan.

Nur, M., \& Hidayah, T. (2017). Pengaruh Metode Latihan dan Power Otot Tungkai terhadap Kelincahan. Journal of Physical Education and Sports.

Sari, R. M. (2015). Aplikasi Biomekanika Nomor Lari 100 Meter Cabang Olahraga Atletik. 


\section{Penerapan IPTEK.}

Sartono, S. (2018). Pengaruh Latihan Double Leg Speed Hop Dan Double Leg Box Boundterhadap Kecepatan Lari 100 Meter. JUARA: Jurnal Olahraga. https://doi.org/10.33222/juara.v3i1.215

Sidik, D. Z. (2014). Mengajar dan Melatih Atletik (4th ed.). Remaja Rosdakarya.

wahyu santosa, D. (2015). Pengaruh Pelatihan Squat Jump Dengan Metode Interval Pendekterhadap Dayaledak (Power) Otot Tungkai. Jurnal Kesehatan Olahraga. 